\title{
Development of General Election Services for Disabilities by using Application SUARAKU In Surabaya
}

\author{
Naili Saidatin, ${ }^{1}$ Misbakhul Munir ${ }^{2}$, Mayang Viorita Oktavia, ${ }^{3}$ Putut Giri Tulus.W, ${ }^{3}$ \\ ${ }^{1}$ Sistem Komputer, Fakultas Teknologi Informasi, Institut Teknologi Adhi Tama Surabaya \\ ${ }^{2}$ Teknik Informatika, Politeknik Elektronika Negri Surabaya \\ ${ }^{3}$ Fisika, Fakultas Sains dan Teknologi, Universitas Airlangga, Surabaya \\ Email: ${ }^{1}$ naili@itats.ac.id,${ }^{2}$ misbakhulmunir11@gmail.com
}

\begin{abstract}
Abstrak. Salah satu wujud demokrasi di Indonesai adalah adanya pemilihan umum untuk menentukan setiap pemimpin disuatu wilayah. Sebagai peserta pemilu tidak semua masyarakat memilki kemampuan yang sama, salah satunya adalah kaum disability yang masih sering merasa kesulitan untuk mengikuti pemilu. Beberapa penyandang disability di Surabaya adalah tuna netra, tuna rungu dan tuna aksara. Untuk menunjang kaum disability mengikuti pelaksanaan pemilihan umum di Surabaya diciptakan sebuah aplikasi yang bernama SUARAKU. SUARAKU adalah aplikasi berbasis android yang dapat membantu penyandang disability khususnya tuna netra, tuna aksara dan tuna rungu dalam mengenali pasangan calon, track record, visi misi dan jadwal kampanye pasangan calon. Aplikasi SUARAKU merupakan salah satu aplikasi untuk membantu para penyandang disabilitas dengan bentuk suara dan gambar. Suara yang digunakan terdiri dari dua macam bahasa yaitu bahasa Jawa dan bahasa Indonesia yang bertujuan untuk memudahkan para pengguna aplikasi ini. Dengan adanya aplikasi SUARKU diharapkan dapat menunjang tercapainya hak kaum disability untuk ikut serta menyuarakan hak dan kewajibannya demi terciptanya negara Indonesia yang adil dan sejahtera.
\end{abstract}

Kata kunci: pemilihan umum, disability, android

\begin{abstract}
One form of democracy in Indonesia is a general election to determine every leader in a region. As an election participant not all people have the same ability, one of them is disability people who still often find it difficult to take part in elections. Some people with disabilities in Surabaya are blind, deaf and illiterate. To support the disability following the general election in Surabaya an application called SUARAKU was created. SUARAKU is an application based on Android mobile that can help people with disabilities, especially blind, illiterate and deaf in identifying candidate pairs, track record, mission vision and campaign schedule of the candidate pairs. SUARAKU can help people with disabilities in the form of sounds and images. The voice used consists of two kinds of languages, namely Javanese and Indonesian which aims to facilitate the users of this application. With the existence of the SUARKU application, it is expected to support the achievement of the disability rights to participate in voicing their rights and obligations in order to create a just and prosperous Indonesia.
\end{abstract}

Keyword: general election, disability, android

\section{Introduction}

The amendment to the 1945 Constitution has had a major impact on the world of politics and power in Indonesia. One of them is the creation of the principle of democracy, where power is no longer fully in the hands of the parliament but all power is determined by the people's tenacity. The existence of elections is one form of democracy in Indonesia. This is done by choosing and voting for candidate leaders who they think will represent their best interests. The rights and obligations of every Indonesian citizen to take part in the election have been regulated in the 1945 Constitution. Therefore, all Indonesian citizens who have fulfilled the requirements have to take part in elections to convey their aspirations for the progress of the Indonesian nation.

As an election participant not all people have the same ability, one of them is disability people who still often find it difficult to take part in elections. Until now, Indonesia still has some people with disabilities which included illiterate, blind and deaf. This has become a special problem that must be addressed in order to realize the principle of social justice for all Indonesian people [1]. During this time the implementation of elections in Indonesia still have some problems because there 
is still a lack of facilities to reduce the difficulties possessed by people with disabilities, so that the principles of fair and fair elections are still difficult to realize.

Surabaya is one of the big cities in Indonesia. According to the Surabaya City Social Service in 2013, the number of people with disabilities was 4,090 people, consisting of 354 blind people and 472 speechless /deaf people [2]. People with visual impairments have limitations in viewing campaign props and difficulties in voting. Illiterate people have limitations in understanding campaign props and are easier to understand in the form of images or sounds. Whereas deaf people have limitations in understanding the purpose of campaign and have difficulty understanding how to vote. Language is one tool that can help communication between humans, as well as the disability people. Based on these factors, in this study the SUARAKU application was created which is one application to help persons with disabilities in the form of sounds and images. The sound used in the SUARAKU application consists of two kinds of languages that aim to support the ease of the disability to use it. SUARAKU is an application that can help people with disabilities, especially blind, illiterate and deaf in identifying candidate pairs, track record, mission, vision, and campaign schedule of the candidate pairs. With this application, it is expected to support the achievement of the disability rights to participate in voicing their rights and obligations for the creation of a just and prosperous Indonesia.

SUARAKU is an Android-based application. Android is one of the developing platforms and makes it easier for devices to be used. As a support for developing this application, researchers use Android studio type 3.3. Android studio is an official IDE (Integrated Development Environment) that is free or open source and functions for the development of android applications [3]. In addition, this application uses a data exchange format that is lightweight, easy to read and easily translated, namely java script object no nation (JSON). JSON is used as an ideal data exchange language, because this language is a text format that does not depend on any programming language, because it uses a commonly used language style such as $\mathrm{C}, \mathrm{C}++$, PERL, PYTON and so on [4].The real manifestation of this research is the creation of SUARAKU application to help disability in participating in general elections. This application also offers digital voting innovations that are easy and efficient for persons with disabilities so that they can support the creation of electoral principles that are honest, open and fair.

\section{Research Methodology:}

The method used in this study is waterfall method, as presented in Figure 1. This method approaches systematically and sequentially, starting from the level of system requirements to the stage of analysis, design, coding, testing, and maintenance [5]. The explanation of this method is as follows:

a. Requirement analysis:

This stage is about communication that aims to understand the software expected by user and collect the data needed to achieve the desired goals. Collection of additional data can be collected from journals, articles and the internet

b. System design

After learning about the needs needed by users, then at this stage system design will be implemented. This stage also helps in determining the hardware and auxiliary systems for overall system development.

c. Implementation

At this stage, the system that has been designed will be developed in a small program called a unit and will be integrated into the next stage. Each unit will be tested to find out its functionality called unit testing.

d. Integration and testing

All units that have been tested will be developed and integrated into the system. Once integrated, the system will be retested to check for any failures or errors.

e. Operation and maintenance 
This stage is the final stage in the waterfall model. At this stage, the finished software will be run and carried out maintenance. Maintenance is done to correct errors that were not found in the previous stages.

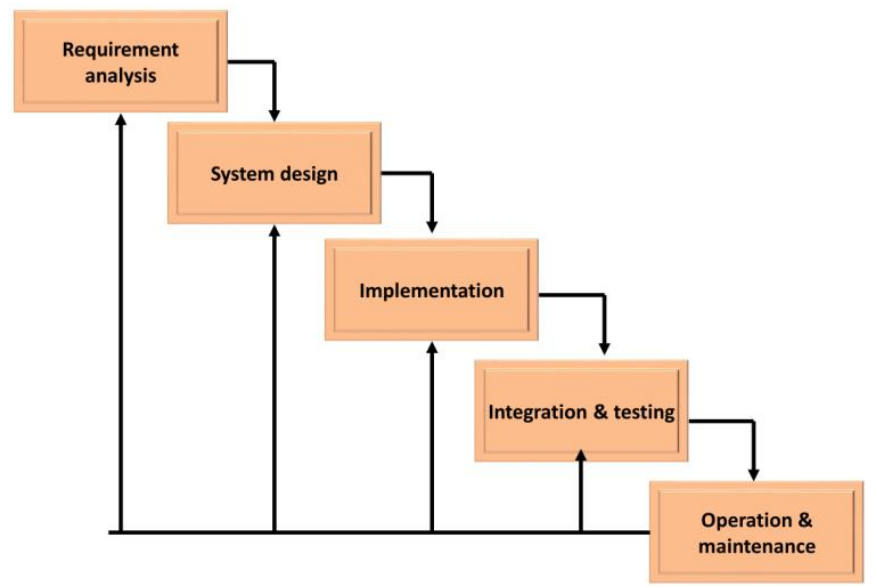

Figure1. Waterfall method [5].

\section{Result and Discussion}

The result from this study is an android-based application called SUARAKU. This application is to help people with disability for participating in mayor elections at Surabaya. The appearance of the SUARAKU application is broadly divided into three groups of menus, where each menu is guided by sound which will make it easier for persons with disabilities. Descriptions for each menu are as follows:

1. First Menu

The first menu will show about language. The type of language chosen is two, namely Javanese and Indonesian. The choice of language type will be guided by a voice that gives instructions if you want to use Indonesian then just tap once, whereas if you want to choose Javanese just tap twice. As an interface between the user and the application being run, a vibration sensor is used with 5 seconds delay for each selected instruction. While the sound in the SUARAKU application is the result of recording the researchers. The purpose of using the Javanese language in this application is to preserve Surabaya's local culture and help tuna sufferers to more easily understand the election campaign. This language selection will be used until the last menu. If the language menu has been selected in the Indonesian language, then the use of this application will use Indonesian language sounds to completion, and so for the Javanese language. Display of the language menu is presented in figure 2.

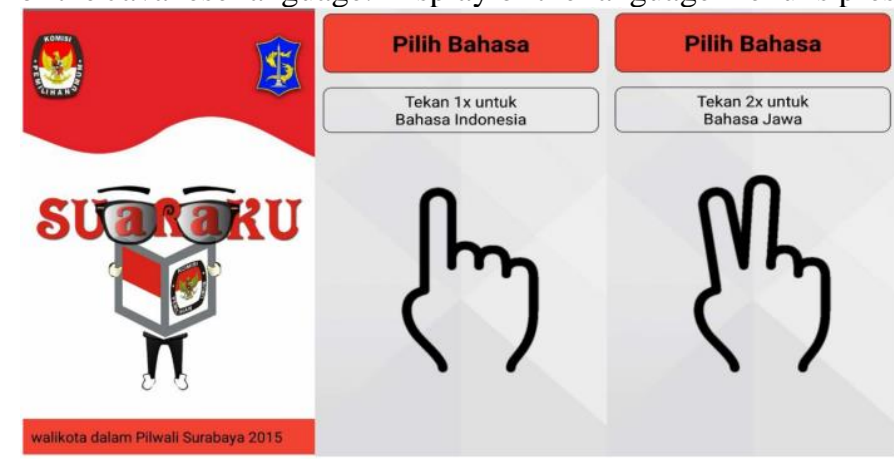

Figure2. Display of Main Menu for Language Selection

2. Second Menu

The second menu in the SUARKAU application is divided into three sub menus which consist of introduction of candidate pairs, simulation of how to choose and campaign schedule. Display of the second menu is presented in Figure 3. For blind and illiterate people, it can be helped by voice, while for the deaf can be helped with pictures. The instructions used 
are the same as the instructions on the first menu. If you want to know the candidate pair then just press once, to learn about the simulation how to choose just tap twice and to find out the campaign schedule by tapping three times. The place to press on the SUARAKU application is not specification, it is used to make it easier for blind people to use this application.

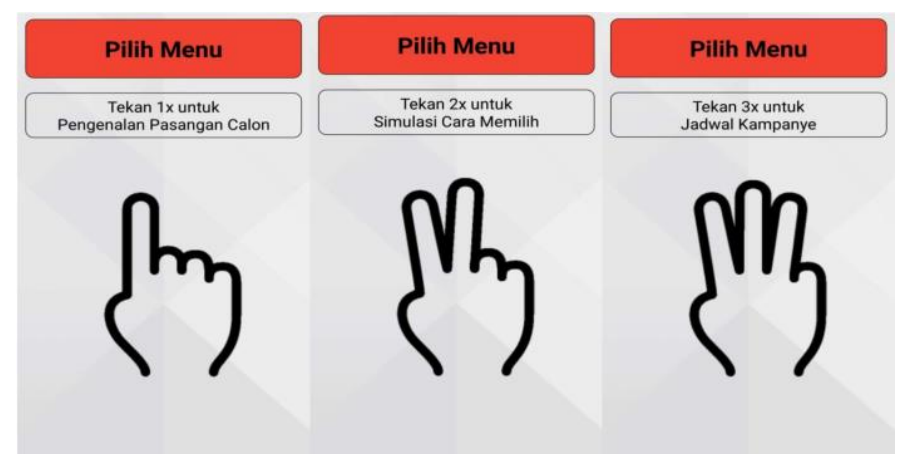

Figure3. Display of the Second Menu for Recognition of Candidate Pairs, Campaign Schedules and Simulation of How to Choose

\subsection{Introduction of Candidate}

This menu consists of photos of each candidate, the name of each candidate pair and from the vision and mission of each candidate. The instructions used in this menu also use sound, where the voice will explain everything related to each candidate pair. After the explanation about the candidate introduction is complete, then to return to the second sub menu, you can use a tap once, then proceed to use the simulation menu to select by tapping twice. The display of the candidate pair introduction sub menu is presented in figure 4 .

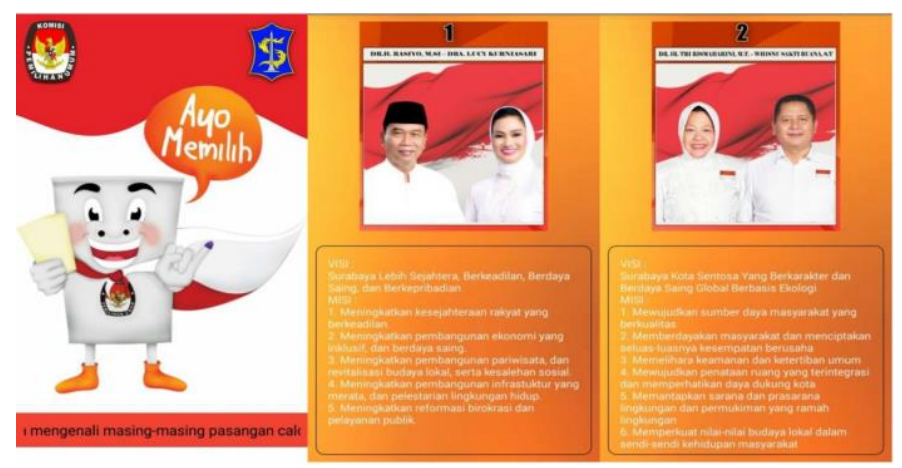

Figure4. Display of Sub Menu About Candidate Pairs

\subsection{Simulation how to choose}

The appearance of the sub menu about the simulation method is presented in Figure 5. The selection method simulation is also done with voice instructions, where if you want to choose a candidate pair in number 1, just tap once and double-tap to select the candidate pair with serial number 2 . At the end of this sub menu, you will be asked for confirmation about the choices made by doing the same order, if you choose the candidate pair number 1 then tap once and double-tap to confirm the choice of candidate pair number two who then select data from each participant will be received by the central computer. To return to the main menu, the instructions used are the same, namely by tapping once. 


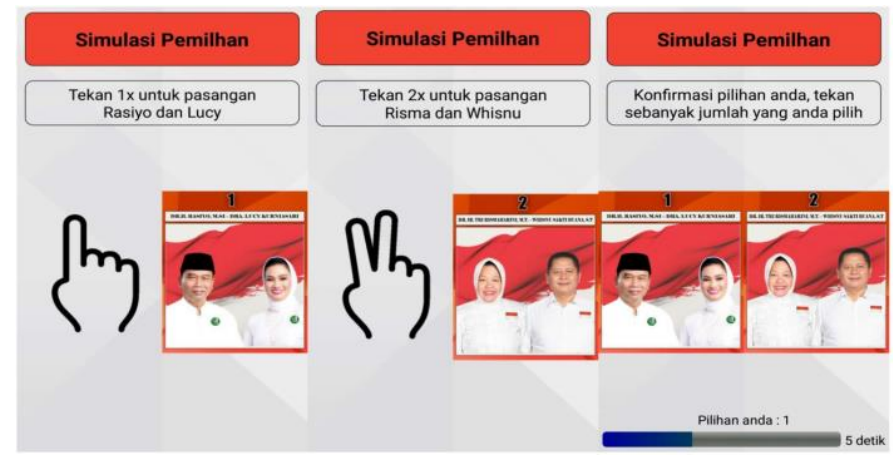

Figure5. Display of Sub Menu About Simulation How to Choose

2.3. Campaign schedule

The campaign schedule sub menu can be done by tapping three times in the second menu. In this sub menu, you will be informed about the schedule and location of the campaign from each candidate pair. The system used in the campaign schedule menu is an application from Google, namely the Google Geocoding API and Reverse Geocoding API. Geocoding functions to convert an address obtained from the geographical coordinates into latitude coordinates which can be used to place markers on the map, whereas for reverse geocoding is the opposite of geocoding which is converting coordinates to an address [6]. The appearance of the sub menu about the campaign schedule is presented in figure 6 .

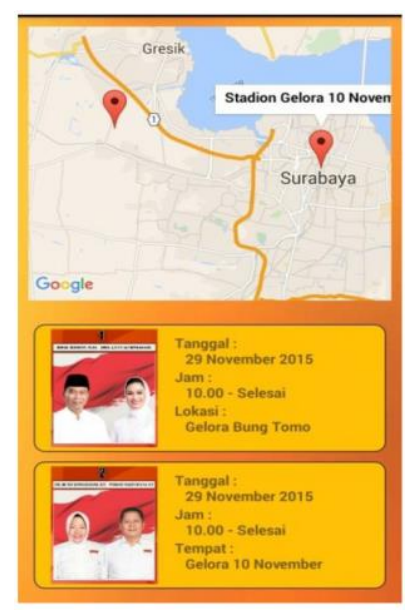

Figure6. Display of Sub Menu about Campaign Schedule

\section{Third menu}

In the third menu there are two choices, where if you want to exit the application you can choose double-tap and if you want to go back to the main menu using a one-time tap. The appearance of the third menu is presented in figure 7. 


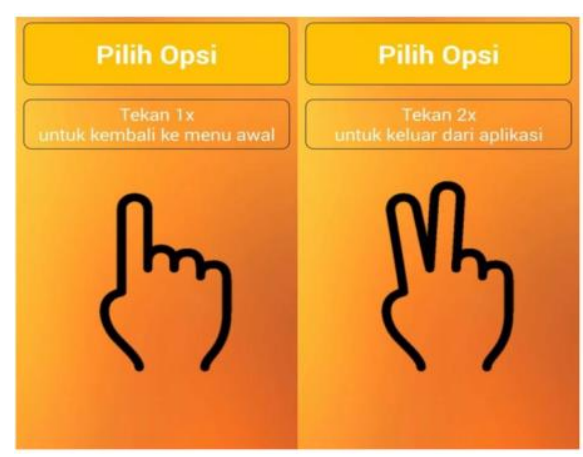

Figure7. Display of third menu

\section{Application testing:}

After the application is complete, the last step in this research is testing the level of ease and usefulness of this application by user directly. The testing of this application was carried out in the activities of PAHLAWAN MUDA Apps Challenge Code for Vote 3.0 Surabaya organized by KPU Surabaya and Telkom Indonesia. The testing of this application was carried out directly by several judges who involved many groups. Among them are Surabaya KPU, PERLUDEM, KPU RI commissioners, and SUWEC who are the developer community in Surabaya and various other parties. Based on the final results, SUARAKU application was got the second rank in the category of disability applications and this application is suitable for persons with disabilities to participate in general elections.

\section{Conclusion:}

SUARAKU is an android-based application that can help people with disabilities, especially blind, illiterate and deaf people in general elections. This application also helps to carry out general elections with overflowing and fair principles, because in this application a polling simulation method is offered that helps disability to record their voting without being influenced by others. Finally, with existence of SUARAKU application is expected to support the achievement of the disability right to participate in general election and creating a fair and prosperous at Indonesia.

\section{References:}

[1] JICA. (2002). Country profile on Disability: Republic of Indonesia. Jakarta: JICA, Planning and Evaluation Department.

[2] Depkes RI .(2013). Basic Health Research 2013: National report. Jakarta: Research and Development Agency, Depkes RI.

[3] Holla.S, Katti.M. (2012). Android Based Mobile Application Development and its security.International Journal of Computer Trends and Technology. Vol: 3 (3).

[4] Flanagan.D. (2011). JavaScript: The Definitive Guide, sixth edition. ISBN: 978-0-596-80552-4

[5] Bassil.Y.(2012) A Simulation Model for the Waterfall Software Development Life Cycle. International Journal of Engineering \& Technology. Vol: 2 (5)

[6] Dincer.A, Uaz.B.(2013). Google Maps JavaScript API Cookbook. ISBN 978-1-84969-882-5 